\title{
Modelling Tsunami Level of Hazard in Pariaman Coastal Area, West Sumatera
}

\author{
Hilza Ikhsanti, Ratna Saraswati*, Nurul Sri Rahatiningtyas \\ Department of Geography, Faculty of Mathematics and Natural Science, Indonesia University, Depok \\ - Indonesia.
}

\begin{abstract}
Pariaman is a coastal area in West Sumatera which is located near the seismic fracture. The Semangko fracture consists of the Sumatran fault that extends from north to south and the subduction zone of the plate is located at the base where the two Indo-Australian plates meet. This study aims to determines the level of tsunami hazard in Pariaman coastal area. This study is designed based on tsunami inundation model. The analysis results show that the coastal area of Pariaman is at high tsunami hazard with an area of $1032,53 \mathrm{Ha}$, area that at middle tsunami hazard with an area $160,39 \mathrm{Ha}$ and area that at low tsunami hazard with an area $88,50 \mathrm{Ha}$.
\end{abstract}

\section{Introduction}

Most of West Sumatra's coastal areas in the western part of Sumatra Island are part of the Eurasia plate process that moves very slowly and relatively moving towards the southeast at a speed of about $0.4 \mathrm{~cm} /$ year. In the western part of the province, there is an interaction between the Eurasian Plate and the Indian Ocean Plate moving northwards at a rate of 7 $\mathrm{cm} /$ year [1]. Sumatera Island is one of the areas located on the periphery of an active plate margin in the world which is showed by the high frequency of earthquake incidence in this region. The spread of earthquakes in this region is not only sourced from the activity of subduction zones, but also from active fault systems along the island of Sumatra [2].

The term "tsunami" is from a Japanese word written in two characters namely "Tsu" which means port and "Nami" which means wave so that the merging of this word can mean a large wave [3]. Tsunamis refer to a series of waves crossing the ocean with wavelengths reaching hundreds of miles when the waves hit the shore will be flooded with most of the lowland areas [4]. In most tsunami events it can cause destruction till loss of life. The main factor that determines the initial size of the tsunami is the level of the vertical sea bottom deformation controlled by the magnitude of the earthquake, the focal depth (the depth below the seabed where the earthquake occurs), the characteristic of faulting and the deterioration of sediment or secondary errors [5]. The area around the west coast of Sumatra is a lowland that has a high level of risk to tsunami hazard. This Tsunami can be triggered by earthquake events originating from the Sunda trench in the region there is a seismic gap that can be a source of earthquake in the future [5]. The condition that most areas in domination by this lowland allows that the west coast of Sumatra will have a significant impact in the event of

\footnotetext{
*Corresponding author: ratna.saraswati@ui.ac.id
} 
a catastrophic tsunami.

Geographically, the city of Pariaman is located on the west coast of the island of Sumatra directly facing the Indian Ocean. The city of Pariaman has a high level of earthquake disaster vulnerability due to its geographical condition, which is close to the Sumatran Seismic Fault (the bowl faults), which is the west of Sumatra, stretching from north to south and a plateseeking zone located at the seabed is a meeting between the two Eurasian and Indo-Australian (Megathrust) plates or the rising fault potentially causing a tsunami in the event of a large earthquake followed by a vertical deformation [6]. According to Dr. Danny H Natawidjaja earthquake geological expert, based on geological research history and seismic cycle records, an earthquake scale of 9.0 Richter scale around a subduction zone off the west coast of Sumatra especially around the Mentawai Islands, currently at the end of the seismic cycle [7].

The tsunami hazard assessment aims to predicted the geographical area that affected by tsunami, the intensity of the tsunami effect and the possibility of the occurrence [8]. Tsunami hazard has many criteria to determinate including studies to investigate and document the frequency and severity of prehistoric and historic tsunami events, and numerical modelling studies with varying degrees of complexity, including worst case scenario simulations and sensitivity analyses to different source, etc. [9]. Based on the possibility that indicated Pariaman coastal area has the tsunami hazard. This study aims to analysis the level of tsunami hazard in Pariaman coastal area using numerical modelling of inundation.

\section{Research Methodology}

The study area is in Pariaman coastal area, West Sumatera. Astronomically, Pariaman is located between 00 ' 33 ' 00 "- 00 ' 40 ' 43" South latitude and 100 ' 4 ' 46 "- 100 ' 10 ' 55" East longitude, that has beach length of $12.00 \mathrm{Km}$. The land area is only 0.17 percent of the land area of West Sumatra province [10]. The tsunami hazard is defined as the high wave of tsunami reaching the coastline and the propagation of tsunami waves to the mainland resulting in a wide inundation. Extensive modeling of inundation is carried out using a model of high decline in tsunami wave advance when reaching land, the equation used to model the high decline of tsunami wave [11]. Tsunami inundation model is an analysis based on GIS spatial analysis method. This study using Arcgis 10.5 tools to determinated tsunami hazard assessment.

$$
H_{\text {loss }}=\frac{167 n^{2}}{H_{0}^{1 / 3}}+5 \sin S
$$

Where:

$\mathrm{H}_{\text {loss }} \quad=$ The decline of water height per meter from the inundation

$n \quad=$ The roughness coefficient

$\mathrm{H}_{0} \quad=$ The water height at the shoreline

$\mathrm{S} \quad=$ Slope

Table 1. Surface Roughness

\begin{tabular}{|l|l|}
\hline \multicolumn{1}{|c|}{ Land use } & \multicolumn{1}{c|}{$\mathrm{n}$} \\
\hline Settlement & 0,045 \\
\hline Bare of sparse & 0,015 \\
\hline Shrub & 0,03 \\
\hline Mangrove & 0,06 \\
\hline
\end{tabular}




\begin{tabular}{|l|l|}
\hline Rice field & 0,02 \\
\hline Irrigation rice field & 0,025 \\
\hline Moor & 0,03 \\
\hline Multiple agriculture & 0,035 \\
\hline River & 0,07 \\
\hline Swamp & 0,01 \\
\hline
\end{tabular}

\section{Result and Discussion}

The potential area of tsunami inundation obtained through cost distance analysis. The parameters used to obtain the cost distance value are the surface roughness coefficient and slope value. The scenario of tsunami wave altitude value on coastline $\left(\mathrm{H}_{0}\right)$ is $5 \mathrm{~m}, 10 \mathrm{~m}$, and $20 \mathrm{~m}$.

Table 2. The Width of Tsunami Inundation Scenario

\begin{tabular}{|c|c|c|c|}
\hline No & $\mathrm{H}_{0}$ & Width (Ha) & Percent (\%) \\
\hline 1 & $5 \mathrm{~m}$ & 9.33 & 0.14 \\
\hline 2 & $10 \mathrm{~m}$ & 70.97 & 1.08 \\
\hline 3 & $20 \mathrm{~m}$ & 260.17 & 3.94 \\
\hline
\end{tabular}

Based on the assumption of a tsunami wave height of 5 meters, the potential tsunami will hit the area with a total area of $9.33 \mathrm{Ha}$ or $0.14 \%$ of the overall area of Pariaman. When using the wave height assumption is 10 meters then the tsunami will impact the area of $70.97 \mathrm{Ha}$ or $1.8 \%$ of the total area of the Pariaman. For the modeling of tsunami inundation with the assumption of a wave height of 20 meters, the area to be affected by the tsunami is 260.17 hectares or $3.94 \%$ of the entire of Pariaman.

The distribution of regions affected by the tsunami with the assumption of a wave height of 5 meters is presented further on the map in Figure 1. Based on the map, it can be seen that the regional distribution that will be affected are in 3 sub-districts located along the coastline west of Sumatra Island. Maps of Tsunami Hazard in Pariaman with $\mathrm{H}_{0}=5 \mathrm{~m}$ in Figure 1.

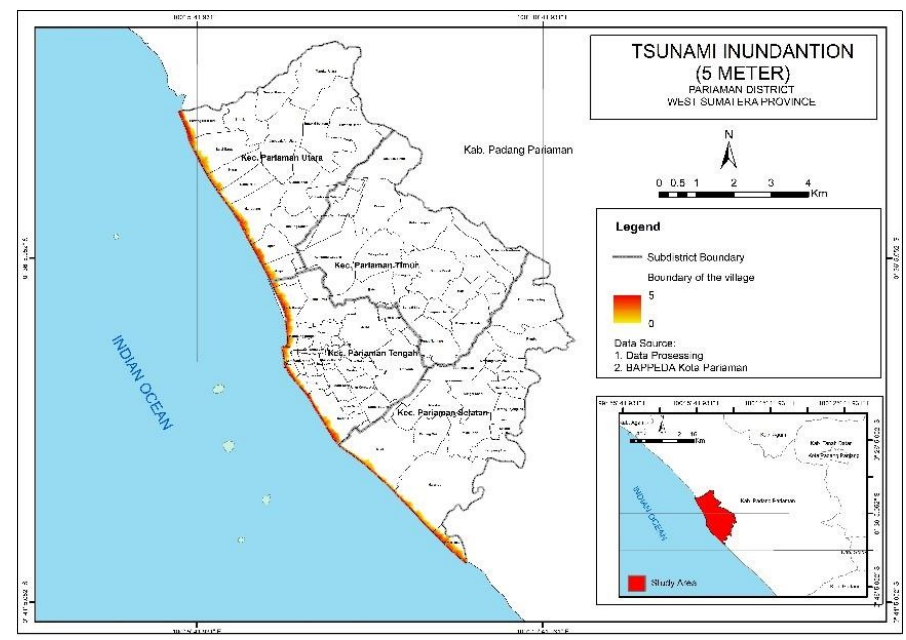

Fig 1. Inundation width $\left(\mathrm{H}_{0}=5 \mathrm{~m}\right)$ in Pariaman 
Modelling tsunami waves with a 5 meters high assumption will have an impact on some villages located in sub-district Pariaman Utara, Pariaman Tengah and Pariaman Selatan. The area of tsunami inset scenario the value of $\mathrm{H}_{0}$ as high as 5 meters can be seen in table 3 .

Table 3. The inundation width with $\mathrm{H}_{0}$ scenario $5 \mathrm{~m}$

\begin{tabular}{|c|c|c|c|c|}
\hline No & Sub-district & Villages & Width (Ha) & Percent (\%) \\
\hline \multirow{3}{*}{1} & \multirow{3}{*}{$\begin{array}{l}\text { Pariaman } \\
\text { Selatan }\end{array}$} & Marunggi & 0.64 & 0.04 \\
\hline & & Pantai Sunur & 0.61 & 0.03 \\
\hline & & Taluk & 0.52 & 0.03 \\
\hline \multirow{4}{*}{2} & \multirow{4}{*}{$\begin{array}{l}\text { Pariaman } \\
\text { Tengah }\end{array}$} & Karan Aur & 0.53 & 0.05 \\
\hline & & Lohong & 0.46 & 0.04 \\
\hline & & Pasir & 0.75 & 0.07 \\
\hline & & Pauh Barat & 0.85 & 0.07 \\
\hline \multirow{7}{*}{3} & \multirow{7}{*}{$\begin{array}{l}\text { Pariaman } \\
\text { Utara }\end{array}$} & Ampalu & 0.77 & 0.04 \\
\hline & & Apar & 0.85 & 0.04 \\
\hline & & Balai Naras & 0.67 & 0.03 \\
\hline & & Manggung & 0.65 & 0.03 \\
\hline & & Naras Hilir & 0.79 & 0.04 \\
\hline & & Naras I & 0.60 & 0.03 \\
\hline & & Padang Birik-birik & 0.64 & 0.03 \\
\hline \multicolumn{2}{|c|}{ Total } & & 9.33 & 0.58 \\
\hline
\end{tabular}

The distribution of affected territories is presented further on the map in Figure 2. Based on the map it can be seen that the regional distribution that will be affected are in 3 subdistricts that are along the coastline west of Sumatra island. The distribution of regions affected in the event of a tsunami wave of as high as 10 meters will have a wider impact compared to the tsunami wave scenario 5 meters. Some villages that will be affected by the tsunami on the assumption 10 meters is Marunggi with an area of 3.56 Ha, Sunur Beach 3.67 $\mathrm{Ha}$, and Taluk area of $5 \mathrm{Ha}$.

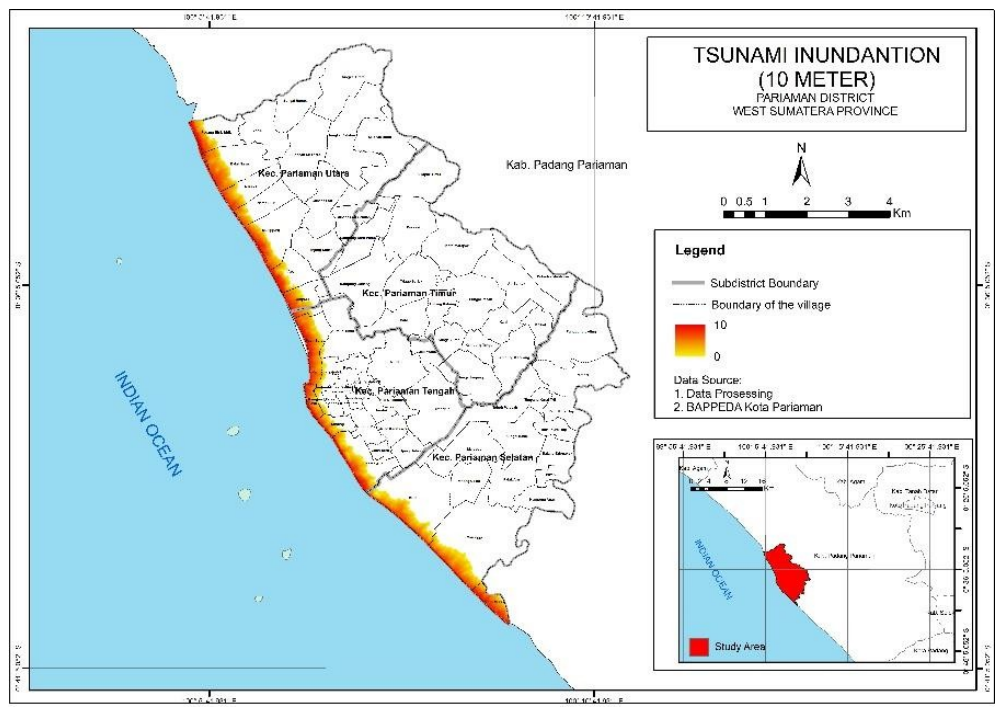

Fig 2. Inundation width $\left(\mathrm{H}_{0}=10 \mathrm{~m}\right)$ in Pariaman

Village located in Pariaman Tengah that will be affected when there is a tsunami with a wave height of 10 meters including Kampung Jawa I with an area of $1.16 \mathrm{Ha}$, Kampung Perak covering 3.13 Ha, Kampung Pondok area of 2.36 Ha, then the village of Karan Aur, 
Lohong, Pasir and Pauh Barat will be affected by an area of 4.52 Ha. Some villages in Pariaman Utara that can be affected if there is a tsunami scenario 10 meters are the villages Ampalu, Apar, Balai Naras, Manggung, Naras Hilir, Naras 1 and Padang Birik-Birik with a potential inundation area of $4.52 \mathrm{Ha}$ in each village. The area of tsunami width scenario the value of $\mathrm{H}_{0}$ as high as 10 meters can be seen in table 4 .

Table 4. The inundation width with $\mathrm{H}_{0}$ Scenario $10 \mathrm{~m}$

\begin{tabular}{|c|c|c|c|c|}
\hline No & Sub-district & Villages & Width (Ha) & Percent $(\%)$ \\
\hline \multirow{3}{*}{1} & \multirow{3}{*}{$\begin{array}{l}\text { Pariaman } \\
\text { Selatan }\end{array}$} & Marunggi & 3.56 & 0.20 \\
\hline & & Pantai Sunur & 3.67 & 0.32 \\
\hline & & Taluk & 5.00 & 0.25 \\
\hline \multirow{8}{*}{2} & \multirow{8}{*}{$\begin{array}{l}\text { Pariaman } \\
\text { Tengah }\end{array}$} & Kampung Jawa I & 1.16 & 0.10 \\
\hline & & Kampung Perak & 3.13 & 0.27 \\
\hline & & Kampung pondok & 2.36 & 0.21 \\
\hline & & Karan Aur & 4.52 & 0.40 \\
\hline & & Lohong & 4.52 & 0.40 \\
\hline & & Pasir & 4.52 & 0.40 \\
\hline & & Pauh Barat & 4.52 & 0.40 \\
\hline & & Pauh Timur & 2.36 & 0.21 \\
\hline \multirow{7}{*}{3} & \multirow{7}{*}{$\begin{array}{l}\text { Pariaman } \\
\text { Utara }\end{array}$} & Ampalu & 4.52 & 0.23 \\
\hline & & Apar & 4.52 & 0.23 \\
\hline & & Balai Naras & 4.52 & 0.23 \\
\hline & & Manggung & 4.52 & 0.23 \\
\hline & & Naras Hilir & 4.52 & 0.23 \\
\hline & & Naras I & 4.53 & 0.23 \\
\hline & & Padang Birik-birik & 4.52 & 0.23 \\
\hline \multicolumn{3}{|c|}{ Total } & 70.97 & 4.73 \\
\hline
\end{tabular}

Some villages that will be affected by the tsunami on the scenario of wave height 20 meters is Marunggi with an area of $12.56 \mathrm{Ha}$, Padang Cakur area of 3.33 Ha, Pantai Sunur with an area of $6.43 \mathrm{Ha}$, and Taluk covering an area of $12.56 \mathrm{Ha}$. Village that located in Pariaman Tengah sub-district that will be affected when there is a tsunami with a wave height 20 meters including Jalan Baru, Jalan Kereta Api, Jawi-Jawi I, Jawi-Jawi II, Kampung Baru, Kampung Jawa, Kampung Pondok, Karan Aur, Lohong, Pasir, Pauh Barat, Pauh Timur, Pondok II and Rawang. In Pariaman Timur sub-district, the affected village is Bato with an area of 3.33 Ha and Kampung Gadang area of 6.24 Ha. Some villages in Pariaman Utara subdistrict that can be affected by a tsunami scenario 20 meters the villages are Ampalu, Apar, Balai Naras, Manggung, Naras Hilir, Naras 1 and Padang Birik-Birik, Sintuk and Tanjung Sabar. Total of all areas of the of Pariaman that can be affected by tsunami inequality is approximately $260.17 \mathrm{Ha}$ or $18 \%$ from the overall hazard area. The following is presented in table 5 which further explains the areas affected by the tsunami scenario 20 meters.

Table 5. The inundation width with $\mathrm{H}_{0}$ scenario $20 \mathrm{~m}$

\begin{tabular}{|l|l|l|c|c|}
\hline No & Sub-district & \multicolumn{1}{|c|}{ Villages } & Width (Ha) & Percent (\%) \\
\hline \multirow{4}{*}{1} & \multirow{3}{*}{$\begin{array}{l}\text { Pariaman } \\
\text { Selatan }\end{array}$} & Marunggi & 12.56 & 0.7 \\
\cline { 3 - 5 } & & Padang Cakur & 3.33 & 0.2 \\
\cline { 3 - 5 } & Pantai Sunur & 6.43 & 0.4 \\
\cline { 3 - 5 } & Taluk & 12.56 & 0.7 \\
\hline \multirow{4}{*}{} & & Jalan Baru & 8.86 & 0.8 \\
\cline { 3 - 5 } & Jalan Kereta Api & 3.33 & 0.3 \\
\cline { 3 - 5 } & & Jawi Jawi I & 6.24 & 0.5 \\
\cline { 3 - 5 } & & Jawi Jawi II & 3.33 & 0.3 \\
\cline { 3 - 5 } & & Kampung Baru & 6.24 & 0.5 \\
\hline
\end{tabular}




\begin{tabular}{|c|c|c|c|c|}
\hline \multirow{10}{*}{2} & \multirow{10}{*}{$\begin{array}{l}\text { Pariaman } \\
\text { Tengah }\end{array}$} & Kampung Jawa I & 8.86 & 0.8 \\
\hline & & Kampung Perak & 8.07 & 0.7 \\
\hline & & Kampung pondok & 8.07 & 0.7 \\
\hline & & Karan Aur & 12.56 & 1.1 \\
\hline & & Lohong & 12.56 & 1.1 \\
\hline & & Pasir & 6.32 & 0.6 \\
\hline & & Pauh Barat & 12.56 & 1.1 \\
\hline & & Pauh Timur & 11.40 & 1.0 \\
\hline & & Pondok II & 8.86 & 0.8 \\
\hline & & Rawang & 6.24 & 0.5 \\
\hline \multirow{2}{*}{3} & \multirow{2}{*}{$\begin{array}{l}\text { Pariaman } \\
\text { Timur }\end{array}$} & Bato & 3.33 & 0.2 \\
\hline & & Kampung Gadang & 6.24 & 0.4 \\
\hline \multirow{9}{*}{4} & \multirow{9}{*}{$\begin{array}{l}\text { Pariaman } \\
\text { Utara }\end{array}$} & Ampalu & 12.56 & 0.6 \\
\hline & & Apar & 12.56 & 0.6 \\
\hline & & Balai Naras & 11.86 & 0.6 \\
\hline & & Manggung & 13.02 & 0.7 \\
\hline & & Naras Hilir & 11.86 & 0.6 \\
\hline & & Naras I & 11.86 & 0.6 \\
\hline & & Padang Birik-birik & 11.86 & 0.6 \\
\hline & & Sintuk & 3.33 & 0.2 \\
\hline & & Tanjung Sabar & 3.33 & 0.2 \\
\hline \multicolumn{3}{|c|}{ Total } & 260.17 & 18 \\
\hline
\end{tabular}

The distribution of affected territories is further presented on the map in Figure 3. Based on the map, it can be seen that the regional distribution will be affected throughout the subdistrict in Pariaman.

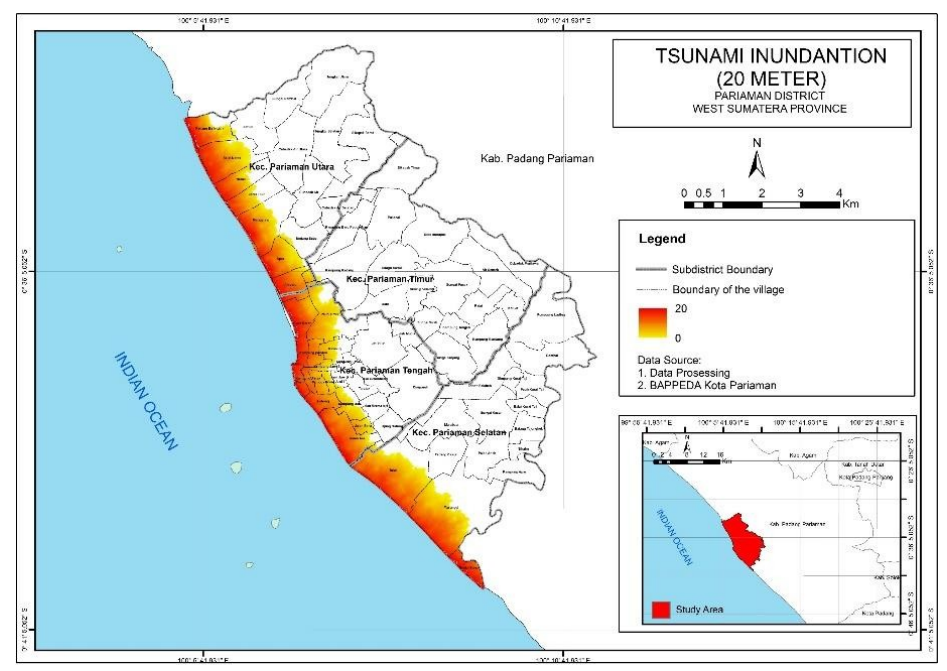

Fig 3. Inundation width $\left(\mathrm{H}_{0}=20 \mathrm{~m}\right)$ in Pariaman

Tsunami Hazard area is the area that has potential to be affected by tsunami. Tsunami hazard levels were obtained based on the widespread modelling of the tsunami. At the determination of the tsunami Hazard area determined based on the assumption of the maximum wave height or the assumed $\mathrm{H}_{0}$ value of 20 meters. The parameters used in the tsunami hazard are the surface roughness coefficient, the tsunami height on the coastline and slope. Based on the figure 4 can be seen how to spread tsunami hazard in Pariaman. Pariaman Timur sub-district is one of the sub-districts whose territory has no high tsunami hazard level. 


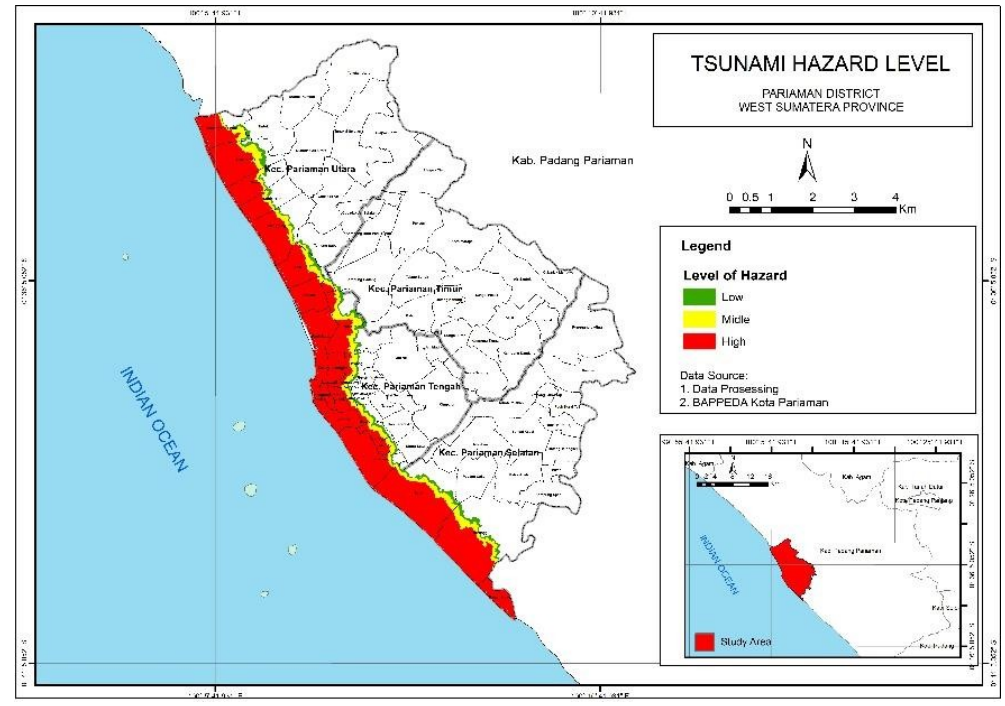

Fig 4. The tsunami hazard level in Pariaman

The area of tsunami hazard which belongs to the low classification with an area 88.50 Ha. The classification of moderate tsunami hazards with an area 160, $38 \mathrm{Ha}$. The classification of high tsunami Hazard with an area 1032.53 ha. Based on the results of data processing of tsunami hazard, the largest area of tsunami danger is at high classification. Figure 4 shows the area of tsunami hazard level in Pariaman, almost all the coastal areas of Pariaman is in high level of tsunami hazard which on the map indicated with a red symbology that covering most of the coastal areas of the Pariaman.

According to table 6 it can be seen that Pariaman coastal area there is a sub-district that has the highest level of danger where in Pariaman Tengah sub-district has 15 villages that have a high level of danger. Pariaman Selatan sub-district has 3 villages that have a high level of danger to the tsunami. Pariaman Utara sub-district there are 7 villages that have a high tsunami hazard level.

Table 6. The Tsunami Hazard Width

\begin{tabular}{|c|c|c|c|c|c|}
\hline \multirow{2}{*}{ No } & \multirow{2}{*}{ Sub-district } & \multirow{2}{*}{ Villages } & \multicolumn{3}{|c|}{ Width of Tsunami Hazard (Ha) } \\
\hline & & & Low & Middle & High \\
\hline \multirow{4}{*}{1} & \multirow{4}{*}{$\begin{array}{l}\text { Pariaman } \\
\text { Selatan }\end{array}$} & Marunggi & 13.19 & 22.57 & 124.08 \\
\hline & & Padang Cakur & 0.02 & 0 & 0 \\
\hline & & Pantai Sunur & 0 & 0 & 30.96 \\
\hline & & Taluk & 11.81 & 20.11 & 142.09 \\
\hline \multirow{10}{*}{2} & \multirow{10}{*}{$\begin{array}{l}\text { Pariaman } \\
\text { Tengah }\end{array}$} & Jalan Baru & 2.34 & 4.51 & 10.74 \\
\hline & & Jawi Jawi I & 1.55 & 5.38 & 3.94 \\
\hline & & Jawi Jawi II & 1.02 & 0.21 & 0 \\
\hline & & Kampung Baru & 6.48 & 11.49 & 14.01 \\
\hline & & Kampung Jawa I & 1.22 & 3.71 & 6.13 \\
\hline & & Kampung Perak & 0 & 0 & 11.94 \\
\hline & & Kampung pondok & 0 & 0 & 23.94 \\
\hline & & Karan Aur & 1.50 & 2.90 & 91.17 \\
\hline & & Lohong & 0 & 0 & 32.60 \\
\hline & & Pasir & 0 & 0 & 21.14 \\
\hline
\end{tabular}




\begin{tabular}{|c|c|c|c|c|c|}
\hline & & Pauh Barat & 0 & 0.51 & 76.66 \\
\hline & & Pauh Timur & 12.24 & 24.47 & 45.52 \\
\hline & & Pondok II & 0 & 0.01 & 19.35 \\
\hline & & Rawang & 3.84 & 7.06 & 10.48 \\
\hline & & Ampalu & 0.74 & 1.81 & 53.20 \\
\hline \multirow{8}{*}{3} & \multirow{8}{*}{$\begin{array}{l}\text { Pariaman } \\
\text { Utara }\end{array}$} & Apar & 5.01 & 10.14 & 53.34 \\
\hline & & Balai Naras & 8.84 & 14.33 & 77.69 \\
\hline & & Manggung & 4.51 & 9.80 & 68.05 \\
\hline & & Naras Hilir & 2.93 & 4.86 & 29.31 \\
\hline & & Naras I & 3.17 & 5.03 & 38.97 \\
\hline & & Padang Birik-birik & 3.95 & 9.45 & 47.22 \\
\hline & & Sintuk & 1.31 & 0.17 & 0 \\
\hline & & Tanjung Sabar & 2.83 & 1.85 & 0.01 \\
\hline \multicolumn{3}{|c|}{ Total } & 88.50 & 160.39 & 1032.53 \\
\hline
\end{tabular}

\section{Conclusions}

Based on modelling tsunami inundation can be seen that the decline in the wave height of the tsunami, increasingly avoiding the coastline, then the tsunami wave will be reduced and will disappear. This would be related to the level of tsunami hazard in the coastal area. The tsunami hazard level would become lower in the area that far from the coastline and it became more high in the area that near from the coastline. The analysis results show that the coastal area of Pariaman is at high tsunami hazard, with an area of 1032,53 Ha, area that at middle tsunami hazard with an area 160,39 Ha and area that at low tsunami hazard with an area 88,50 Ha.

\section{Acknowledgement}

The author would like to thank Directorate of Research and Community Service (DRPM) Universitas Indonesia, which has supported this research in Publikasi Terindeks Internasional (PUTI) Prosiding UI Year 2020 with contract number NKB-1037/UN2.RST/HKP.05.00/2020.

\section{References}

1. Setyonegoro, Wiko. Gempabumi Padang 30 September 2009 dan Potensi Tsunaminya. Buletin Meteorologi Klimatologi dan Geofisika, 7(3), 164-171. (2013).

2. Lasitha, S., Radhakrishna, M., \& Sanu, T. Seismically active deformation in the Sumatra-Java trench-arc region: Geodynamic implications. Current Science, 90(5), 690-696. (2006).

3. Domroes, Manfred (ed.). 2006. After the tsunami: Relief and rehabilitation in Sri Lanka Restarting towards the future. New Delhi, India: Mosaic Books

4. Helal, M.A. Tsunamis, Generation and Mathematical Modeling. Nova Science Publisher, Inc, pp. 225-246. (2010).

5. Pattiaratchi, C. B. (2005). Tsunamis-Their Causes and Effects. University of Western Australia ED 2067 CP.

6. Purbani, D., Salim, H. L., Ramdhan, M., Prihantono, J., \& Dewi, L. C. Penentuan Tempat Evakuasi Sementara (Tes), Berdasarkan Kapasitasnya Di Kota Pariaman Dengan Analisis Sistem Informasi Geografis (SIG), (BNPB 2009), 21-22.(2015)

7. Ihsan, F., \& Pramukanto, Q. Perencanaan Lanskap Kota Pariaman Provinsi Sumatera 
Barat Berbasis Mitigasi Tsunami. Jurnal Lanskap Indonesia, 9(1), 1-12. (2017).

8. Strunz, G., Post, J., Zosseder, K., Wegscheider, S., Mück, M., Riedlinger, T., ... \& Harjono, H. Tsunami risk assessment in Indonesia. Natural Hazards and Earth System Sciences, (11), 67-82. (2011)

9. González, F. I., et al. Probabilistic tsunami hazard assessment at seaside, Oregon, for near-and far-field seismic sources. Journal of Geophysical Research: Oceans 114.C11 (2009).

10. Badan Pusat Statistik (BPS) Kota Pariaman. Kota Pariaman Dalam Angka 2020. (2020)

11. Berryman, K. Review of Tsunami Hazard and Risk in New Zealand. New Zealand: New Zealand: Institute of Geological \& Nuclear Sciences. (2006) 